\title{
CORRESPONDENCE
}

\section{THE AGE OF THE HIGHLAND SCHISTS}

SIR,-Dr. J. G. C. Anderson's comprehensive account of the Highland Border rocks (Trans. Roy. Soc. Edin., 1947, 61, 479) appears to take us several steps towards a dispersal of the depressing mists of conflicting opinions which have too long enveloped the Highlands.

The following more recent developments all have an important bearing on the subject : the vindication of Sir Edward Bailey's Islay and Loch Awe sequences by Dr. Allison ; Sir Edward's acceptance of Mr. Carruthers's extended Eilde Flag-Dalradian sequence in the Lochaber country, and his abandonment in the light of Dr. McCallien's work in Donegal of the elusive slide between the Islay and Loch Awe successions ; Dr. Richey and Professor Kennedy's elucidation of a Sub-Moine complex in Morar which appears to put the reality of some, at least, of the much debated Lewisian inliers in the Moines beyond question; Professor Read's demonstration of the order of deposition in the Banffshire Dalradians; and Mr. Hartley's of the Llandeilian age of the highest Border Rocks in Tyrone and of the importance in that area of intra-Ordovician orogeny and intrusion. Dr. Anderson now synthesizes the evidence along the Border Fault, and amongst other things gives the death blow to Gregory's unpopular Lennoxian.

Not least in importance of recent advances has been Dr. Pringle's discovery of trilobites in the Leny Limestone, on the basis of which Dr. Anderson claims a Cambrian age for the upper part, at least, of the Dalradians. If the latter pass downwards conformably into the Moines it would seem that they must cover not only all Middle and Lower Cambrian times, but something of the interval between Cambrian and Torridonian as well, and Peach's view of the equivalence of Torridonian and Moines is correspondingly strengthened.

There is a corollary to Dr. Anderson's theorem of Cambrian Dalradians to which attention may be drawn. The trilobites discovered by Dr. Pringle at Callander belong to the American genus Pagetia, which is unknown elsewhere in Europe; Shimer and Shrock give its distribution as "S. Appalachians and Cordilleran region; Australia". Here, then, we have an American faunal element on the south-eastern side of the Highlands, and thus the Dalradian country cannot be regarded as a land-barrier separating American and Anglo-Welsh Cambrian provinces. Instead it would seem that we should look in the region of the Irish Sea, (Anglesey, the Lake District, the Southern Uplands), where Cambrian, except for the disputed Bray Series, is unknown in the sense of preTremadoc, and may well be non-existent. The Ingletonian-if indeed pre-Cambrian-may be a part of such a barrier, and even if Ordovician 
must, like the Watch Hill Grits, point to the existence of ancient crystalline rocks near by.

\section{Geology DePT.,}

UNIVERSITY OF LEEDS. 8th November, 1947.

J. SELWyn Turner.

\section{QUERY AS TO THE TEMPO OF AUSTRALIAN DENUDATION}

SIR,-The conclusions of various workers in eastern Australian States indicate the survival there of extensive relics of very ancient land surfaces which have been continuously subject to denudation throughout several geological periods.

Andrews, ${ }^{1}$ who has found very extensive residuals of peneplains forming a high plateau and a somewhat lower benchland in the New England district of New South Wales, has attributed the highest wellpreserved peneplain (itself surmounted by some monadnocks) to a cycle interrupted in the Cretaceous period.

Basaltic lava flows of Oligocene or early Miocene age survive extensively in the New England district, and Voisey ${ }^{2}$ has found that they bury a land surface of rather strong relief. The high altitude at which the residuals of the lava now stand is, therefore, in part original : they have been high enough above base-level to be subject to erosion for several geological periods, and yet they have escaped destruction.

Craft ${ }^{3}$ recognizes a Triassic surface of almost perfect peneplanation (never since buried) in the Blue Mountains, and this, with flanking benchlands, makes a composite surface in southern New South Wales which was, he claims, in existence with a configuration very much like that of the present day (though then somewhat lower as a whole) prior to the outpouring over parts of it of Middle Tertiary basalts.

- In Victoria according to Hills ${ }^{4}$ the most ancient land surface survives in some plateau residuals on areas of particularly resistant rocks that have been at a fairly high altitude ever since the interruption by upheaval of a Cretaceous cycle of erosion. A later and lower-standing peneplain, extensively but imperfectly developed at the expense of the dwindling Cretaceous surface, was buried, together with monadnocks rising above it, under Oligocene basalts, and the compound mass has

${ }^{1}$ E. C. Andrews, The Geology of the New England Plateau, Part I : Physiography. Rec. Geol. Surv. N.S.W., 7 (4), pp. 281-300, 1904.

2 A. H. Voisey, The Tertiary Land Surface in Southern New England, Jour. and Proc. Roy. Soc. N.S.W., 76, pp. 82-5, 1942.

${ }^{3}$ F. A. Craft, The Surface History of Monaro, N.S.W., and The Coastal Tablelands and Streams of N.S.W., Proc. Linn. Soc. N.S.W., 58, pp. 229- 244 and $437-460,1933$.

E. S. Hills, Some Fundamental Concepts in Victorian Physiography, Proc. Ray. Soc. Vie., 47, pp: 158-174, 1934. 